\title{
Mealybugs (Hemiptera: Pseudococcidae) species on Economically Important Fruit Crops in Sri Lanka
}

\author{
U.G.A.I. Sirisena ${ }^{*}$, G.W. Watson ${ }^{1}$, K.S. Hemachandra ${ }^{2}$ and H.N.P. Wijayagunasekara ${ }^{2}$
}

\author{
Postgraduate Institute of Agriculture \\ University of Peradeniya \\ Sri Lanka
}

\begin{abstract}
In recent years, mealybugs (Hemiptera: Pseudococcidae) have become an important pest of fruit crops in Sri Lanka due to their accidental introductions and invasiveness. Awareness, early detection of invasive species and immediate implementation of control methods could minimize the economic losses caused by them. A survey was conducted during the period 2011 - 2013 to identify the mealybug species found in fruit crops, and document the distribution and the host range of fruit crops for each species. Eleven mealybug species belonging to seven genera were identified. Among them, Planococcus lilacinus (Cockerell) and Rastrococcus invadens (Williams) were the dominant species and both were highly polyphagous. Other species collected were Dysmicoccus

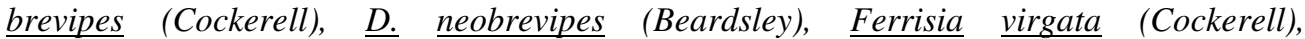
Maconellicoccus hirsutus (Green), Paracoccus marginatus (Williams and Granara de

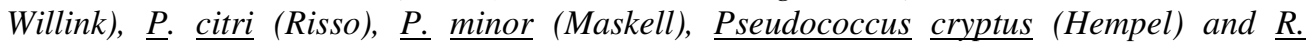
iceryoides (Green). The taxonomy, distribution and fruit crop host ranges of the recorded species were documented and their pest status on fruit crops was discussed. An identification key to mealybug species in fruit crops in Sri Lanka was developed together with a pictorial guide for the species collected in the survey.
\end{abstract}

Keywords: Fruit crops, identification key, invasive species, mealybugs, Sri Lanka

\section{INTRODUCTION}

A wide diversity of perennial and herbaceous tropical-fruit crops are grown in Sri Lanka. The herbaceous group comprises crops like banana, pineapple and papaya; the perennial plants include trees, shrubs and vines (Verheij \& Coronel, 1992). The fruit industry of Sri Lanka is dominated by banana, citrus crops (lime, sweet orange and mandarin), mango, passion fruit and pineapple, both in cultivated land area and production volume. Fruits are exported mainly to United Arab Emirates, India and the Maldives and accounted for 55\% of fruit exports (Ceylon Chamber of Commerce, 2011). Many other under-utilized, seasonal fruits e.g. gaduguda, mangosteen and woodapple are grown to supply for local markets (Pushpakumara, et al., 2011).

Fruits are grown virtually everywhere in Sri Lanka from the coastal belt to higher elevations, mainly in home gardens. Commercial production of fruit crops regularly begins on or near areas with a little agricultural development. Many insect and mite pests attack fruit crops and

California Department of Food and Agriculture, Plant Pest Diagnostic Center, Sacramento, California, USA

2 Department of Agricultural Biology, Faculty of Agriculture, University of Peradeniya, Sri Lanka

Corresponding author: anuraindra@gmail.com 
most of them are polyphagous, e.g. mites (Acarina) (Helle \& Sabelis, 1985), fruit flies (Diptera; Tephritidae) (White \& Elson-Harris, 1994), scale insects (Hemiptera: Coccoidea) (Rosen, 1990) and thrips (Thysanoptera) (Parker et al., 1995). The arthropod fauna in unexploited areas is likely to spread to new areas, creating opportunities for colonization on fruit crops (Entwistle, 1972).

In recent years, mealybugs have become more important than ever before on cultivated crops in Sri Lanka because of accidental introductions of invasive species like Paracoccus marginatus Williams \& Granara de Willink, Phenacoccus solenopsis (Tinsley), Dysmicoccus neobrevipes Beardsley, Rastrococcus rubellus Williams and Brevennia rehi Lindinger (Galanihe et al., 2010; Galanihe \& Watson, 2013; Sirisena et al., 2013a). The introduction of $P$. marginatus resulted in an epidemic and caused severe crop damage, particularly to papaya (Galanihe et al., 2010).

Nymphs and adult female mealybugs suck plant sap and some species cause considerable economic damage to fruit crops. Sap depletion results in loss of plant vigour, reduced yield, poor growth, dieback of twigs and branches, leaf drop, and sometimes death of the plant (McKenzie, 1967; Miller \& Kosztarab, 1979; Williams, 1985; Miller et al., 2002). Mealybugs also cause indirect damage by fouling foliage with their sugary honeydew excretions, providing a growth medium for sooty mould fungi. Mold growth blocks light and air from the leaves, interfering with photosynthesis, and may cause poor growth and fruit yield, leaf drop, reduced fruit sugar content and disfigured fruits (McKenzie, 1967; Miller \& Kosztarab, 1979).

Ernest E. Green's work on the Pseudococcidae of Sri Lanka (Green, 1922), and several subsequent publications (Williams, 2004; Sirisena et al., 2012a; Ben-Dov, 2013; Galanihe \& Watson, 2013) have recorded a total of 58 mealybug species in 25 genera from the island to date. Seventeen of these species are potential pests of fruit crops. However since Green's work, there has been no methodical study of mealybugs in Sri Lanka. Thorough knowledge of the mealybug fauna on fruit crops is needed to enable early detection and control of any future mealybug introductions. A survey was therefore conducted in $2011-2013$ to identify the mealybug species found on fruit crops, and to document the distribution and fruit crop host range of each species.

\section{METHODOLOGY}

The study was carried out at the Department of Agricultural Biology, Faculty of Agriculture of University of Peradeniya Sri Lanka, during 2011 to 2013 in collaboration with California Department of Food and Agriculture, Plant Pest Diagnostic Center, Sacramento, California, USA. In the island-wide survey of mealybugs on fruit crops in Sri Lanka in 2011 - 2013, the fruit species sampled were banana, mango, pineapple, papaya, passion fruit, citrus crops, guava, pomegranate, anona, rambutan, nelli, gaduguda and durian.

In the field, mealybugs were collected on pieces of infested plant material into labeled Ziploc polythene bags $(15 \times 20 \mathrm{~cm})$. To avoid damaging them, live specimens were not picked off the host-plant. Bagged samples were kept cool and shaded, and were taken to the laboratory for sorting using a dissection microscope and preservation.

In the laboratory, the colour of the body contents of each species was assessed by smearing some of the live insects on white paper. Small pieces of infested plant material were isolated 
and placed in $80 \%$ alcohol in labeled, screw-topped Nalgene vials (3 or $5 \mathrm{ml}$ capacity, as appropriate), to kill and preserve the mealybugs. To prevent body blackening, vials of freshly killed material were sealed and immediately kept in a water bath at $100^{\circ} \mathrm{C}$ for $15-20$ minutes to denature the enzymes and ensure optimal fixation of the body contents. Permanent slide mounts of specimens were prepared at California Department of Food and Agriculture Plant Pest Diagnostic Center (CDFA-PPDC) using the method given by Sirisena et al. (2012b). The resultant archival-quality preparations were deposited in the reference insect collection at the Department of Agricultural Biology, Faculty of Agriculture, University of Peradeniya, Sri Lanka (UPSL).

Slide-mounted specimens were examined using a Zeiss compound microscope with phase contrast illumination and magnifications of $\mathrm{x} 25-\mathrm{x} 800$. The species were identified using published keys (Williams \& Granara de Willink, 1992; Williams,2004), and comparison with reference specimens in the California State Collection of Arthropods (CSCA) at CDFAPPDC, and the reference collection at UPSL.

The fruit crop range of each mealybug species was determined as the fruit species on which the mealybugs were collected during the survey. The level of infestation by each mealybug species was assessed at each site, as follows: $<5$ mealybugs per leaf (very low), 5 to 10 mealybugs per leaf (low), 10 to 15 mealybugs per leaf (medium), 15 to 25 mealybugs per leaf (high) or $>25$ mealybugs per leaf (very high). The pest status of each mealybug species was based on an average of its infestation levels found during the survey. The agroecological zone codes used are defined in Punyawardena et al. (2003).

\section{RESULTS AND DISCUSSION}

Eleven mealybug species belonging to seven genera were collected from 13 fruit crops during the survey. Mango, guava, pomegranate, anona and citrus crops were highly susceptible to mealybug attack and each was attacked by two or more species whereas the other fruit crops were each attacked by only one mealybug species (Table 1).

The most serious pest mealybugs on fruits were: Pl. lilacinus on five different fruit crops, $R$. invadens on four, $P a$. marginatus on papaya, $D$. brevipes on pineapple, and $D$. neobrevipes on banana. M. hirsutus was of medium importance on three fruit crops. Papaya mealybug (Pa. marginatus) was found in almost every agro-ecological zone surveyed (Table 1). Locations of each sampling site of respective agro-ecological zone are given in the (Table 2) 
Table 1. Mealybug species associated with fruit crops and their distribution in different agro-ecological zones in Sri Lanka as per the survey carried out in 2011-2013.

\begin{tabular}{|c|c|c|c|}
\hline Fruit crop & Mealybug species & $\begin{array}{c}\text { Agro-ecological } \\
\text { zones* }\end{array}$ & $\begin{array}{l}\text { Infestation } \\
\text { level }\end{array}$ \\
\hline \multirow{2}{*}{$\begin{array}{l}\text { Banana } \\
\text { (Musa acuminata } \\
\text { Colla) }\end{array}$} & $\begin{array}{l}\text { Dysmicoccus neobrevipes } \\
\text { Beardsley }\end{array}$ & $\begin{array}{l}\text { DL1, DL3, DL5, WL2a, } \\
\text { WL2b, WU3 }\end{array}$ & High \\
\hline & $\begin{array}{l}\text { Pseudococcus cryptus } \\
\text { Hempel }\end{array}$ & $\begin{array}{l}\text { DL3, DL5, WL2a, WL2b, } \\
\text { WU3 }\end{array}$ & Low \\
\hline \multirow{3}{*}{$\begin{array}{l}\text { Mango } \\
\text { (Mangifera indica } \\
\text { L.) }\end{array}$} & $\begin{array}{l}\text { Planococcus lilacinus } \\
\text { (Cockerell) }\end{array}$ & $\begin{array}{l}\text { DL1, DL2b, DL5, WL2a, } \\
\text { WL2b, WM3b, WU3 }\end{array}$ & High \\
\hline & $\begin{array}{l}\text { Rastrococcus invadens } \\
\text { Williams }\end{array}$ & $\begin{array}{l}\text { DL1, DL2b, DL5, WL2a, } \\
\text { WL2b, WU3 }\end{array}$ & High \\
\hline & $\begin{array}{l}\text { Rastrococcus iceryoides } \\
\text { (Green) }\end{array}$ & DL2b, DL5, WL2a & Medium \\
\hline \multirow{2}{*}{$\begin{array}{l}\text { Pineapple } \\
\text { (Ananas comosus } \\
\text { (L.) } \\
\text { Papaya } \\
\text { (Carica papaya L.) }\end{array}$} & $\begin{array}{l}\text { Dysmicoccus brevipes } \\
\text { (Cockerell) }\end{array}$ & IL1a, WL2a & High \\
\hline & $\begin{array}{l}\text { Paracoccus marginatus } \\
\text { Williams and Granara de } \\
\text { Willink }\end{array}$ & $\begin{array}{l}\text { IL1a, DL2b, DL3, DL5, } \\
\text { WL2a }\end{array}$ & Very high \\
\hline \multirow[t]{4}{*}{$\begin{array}{l}\text { Guava } \\
\text { (Psidium guajava L.) }\end{array}$} & $\begin{array}{l}\text { Planococcus lilacinus } \\
\text { (Cockerell) }\end{array}$ & $\begin{array}{c}\text { DL1, DL2b, DL5, WL2a, } \\
\text { WL2b, WM3b, }\end{array}$ & High \\
\hline & $\begin{array}{l}\text { Maconellicoccus hirsutus } \\
\text { (Green) }\end{array}$ & $\begin{array}{l}\text { DL1, DL2b, DL5, WL2a, } \\
\text { WM3b }\end{array}$ & Medium \\
\hline & $\begin{array}{l}\text { Rastrococcus invadens } \\
\text { Williams }\end{array}$ & $\begin{array}{l}\text { DL1, DL2b, DL5, WL2a, } \\
\text { WL2b, WU3 }\end{array}$ & Medium \\
\hline & $\begin{array}{l}\text { Ferrisia virgata } \\
\text { (Cockerell) }\end{array}$ & $\begin{array}{l}\text { DL1, DL2b, DL5, WL2a, } \\
\text { WM3b }\end{array}$ & Low \\
\hline \multirow{3}{*}{$\begin{array}{l}\text { Pomegranate } \\
\text { (Punica granatum } \\
\text { L.) }\end{array}$} & $\begin{array}{l}\text { Planococcus lilacinus } \\
\text { (Cockerell) }\end{array}$ & $\begin{array}{l}\text { DL1, DL2b, DL5, WL2a, } \\
\text { WL2b, WM3b, WU3 }\end{array}$ & High \\
\hline & $\begin{array}{l}\text { Maconellicoccus hirsutus } \\
\text { (Green) }\end{array}$ & $\begin{array}{c}\text { DL1, DL2b, DL5, WL2a, } \\
\text { WM3b }\end{array}$ & Medium \\
\hline & $\begin{array}{l}\text { Ferrisia virgata } \\
\text { (Cockerell) }\end{array}$ & $\begin{array}{c}\text { DL1, DL2b, DL5, WL2a, } \\
\text { WM3b }\end{array}$ & Low \\
\hline
\end{tabular}




\begin{tabular}{|c|c|c|c|}
\hline Citrus & Planococcus lilacinus & DL1, DL2b, WL2a, & High \\
\hline (Christm.) Swingle; & Rastrococcus invadens & DL1, DL2b, DL5, & High \\
\hline C. sinensis (L.) & Williams & WL2a, WL2b, WU3 & \\
\hline $\begin{array}{l}\text { Osbeck } \\
\text { and }\end{array}$ & Planococcus citri (Risso) & $\begin{array}{l}\text { DL5, WL2a, WL2b, } \\
\text { WU3 }\end{array}$ & Medium \\
\hline \multirow[t]{3}{*}{$\begin{array}{l}\text { C. reticulata } \\
\text { Blanco) }\end{array}$} & $\begin{array}{l}\text { Planococcus minor } \\
\text { (Maskell) }\end{array}$ & $\begin{array}{l}\text { DL5, WL2a, WL2b, } \\
\text { WU3 }\end{array}$ & Medium \\
\hline & $\begin{array}{l}\text { Pseudococcus cryptus } \\
\text { Hempel }\end{array}$ & $\begin{array}{l}\text { DL3, DL5, WL2a, } \\
\text { WL2b, WU3 }\end{array}$ & Low \\
\hline & $\begin{array}{l}\text { Dysmicoccus neobrevipes } \\
\text { Beardsley }\end{array}$ & $\begin{array}{c}\text { DL1, DL3, DL5, } \\
\text { WL2a, WL2b, WU3 }\end{array}$ & Low \\
\hline \multirow[t]{4}{*}{$\begin{array}{l}\text { Anona } \\
\text { (Annona squamosa } \\
\text { L.) }\end{array}$} & $\begin{array}{l}\text { Planococcus lilacinus } \\
\text { (Cockerell) }\end{array}$ & $\begin{array}{l}\text { DL1, DL2b, DL5, } \\
\text { WL2a, WL2b, WM3b, } \\
\text { WU3 }\end{array}$ & High \\
\hline & $\begin{array}{l}\text { Maconellicoccus hirsutus } \\
\text { (Green) }\end{array}$ & $\begin{array}{l}\text { DL1, DL2b, DL5, } \\
\text { WL2a, WM3b }\end{array}$ & Medium \\
\hline & $\begin{array}{l}\text { Ferrisia virgata } \\
\text { (Cockerell) }\end{array}$ & $\begin{array}{l}\text { DL1, DL2b, DL5, } \\
\text { WL2a, WM3b }\end{array}$ & Low \\
\hline & $\begin{array}{l}\text { Dysmicoccus neobrevipes } \\
\text { Beardsley }\end{array}$ & $\begin{array}{c}\text { DL1, DL3, DL5, } \\
\text { WL2a, WL2b, WU3 }\end{array}$ & Low \\
\hline $\begin{array}{l}\text { Passion fruit } \\
\text { (Passiflora edulis } \\
\text { Sims) }\end{array}$ & $\begin{array}{l}\text { Maconellicoccus hirsutus } \\
\text { (Green) }\end{array}$ & $\begin{array}{l}\text { DL1, DL2b, DL5, } \\
\text { WL2a, WM3b }\end{array}$ & Low \\
\hline $\begin{array}{l}\text { Rambutan } \\
\text { (Nephelium } \\
\text { lappaceum } \\
\text { L.) }\end{array}$ & $\begin{array}{l}\text { Rastrococcus invadens } \\
\text { Williams }\end{array}$ & $\begin{array}{l}\text { DL1, DL2b, DL5, } \\
\text { WL2a, WL2b, WU3 }\end{array}$ & Medium \\
\hline $\begin{array}{l}\text { Nelli } \\
\text { (Phyllanthus } \\
\text { emblica L.) }\end{array}$ & $\begin{array}{l}\text { Rastrococcus invadens } \\
\text { Williams }\end{array}$ & $\begin{array}{l}\text { DL1, DL2b, DL5, } \\
\text { WL2a, WL2b, WU3 }\end{array}$ & Very low \\
\hline $\begin{array}{l}\text { Gaduguda } \\
\text { (Baccauria } \\
\text { motleyana (Muella. } \\
\text { Arg.) }\end{array}$ & $\begin{array}{l}\text { Planococcus minor } \\
\text { (Maskell) }\end{array}$ & $\begin{array}{l}\text { DL5, WL2a, WL2b, } \\
\text { WU3 }\end{array}$ & Very low \\
\hline $\begin{array}{l}\text { Durian } \\
\text { (Durio zibethinus } \\
\text { Rumph. ex Murray) }\end{array}$ & Planococcus citri (Risso) & $\begin{array}{l}\text { DL5, WL2a, WL2b, } \\
\text { WU3 }\end{array}$ & Very low \\
\hline
\end{tabular}


Table 2. Distribution of Mealybug species of fruit crops in Sri Lanka as per the survey carried out in 2011-2013.

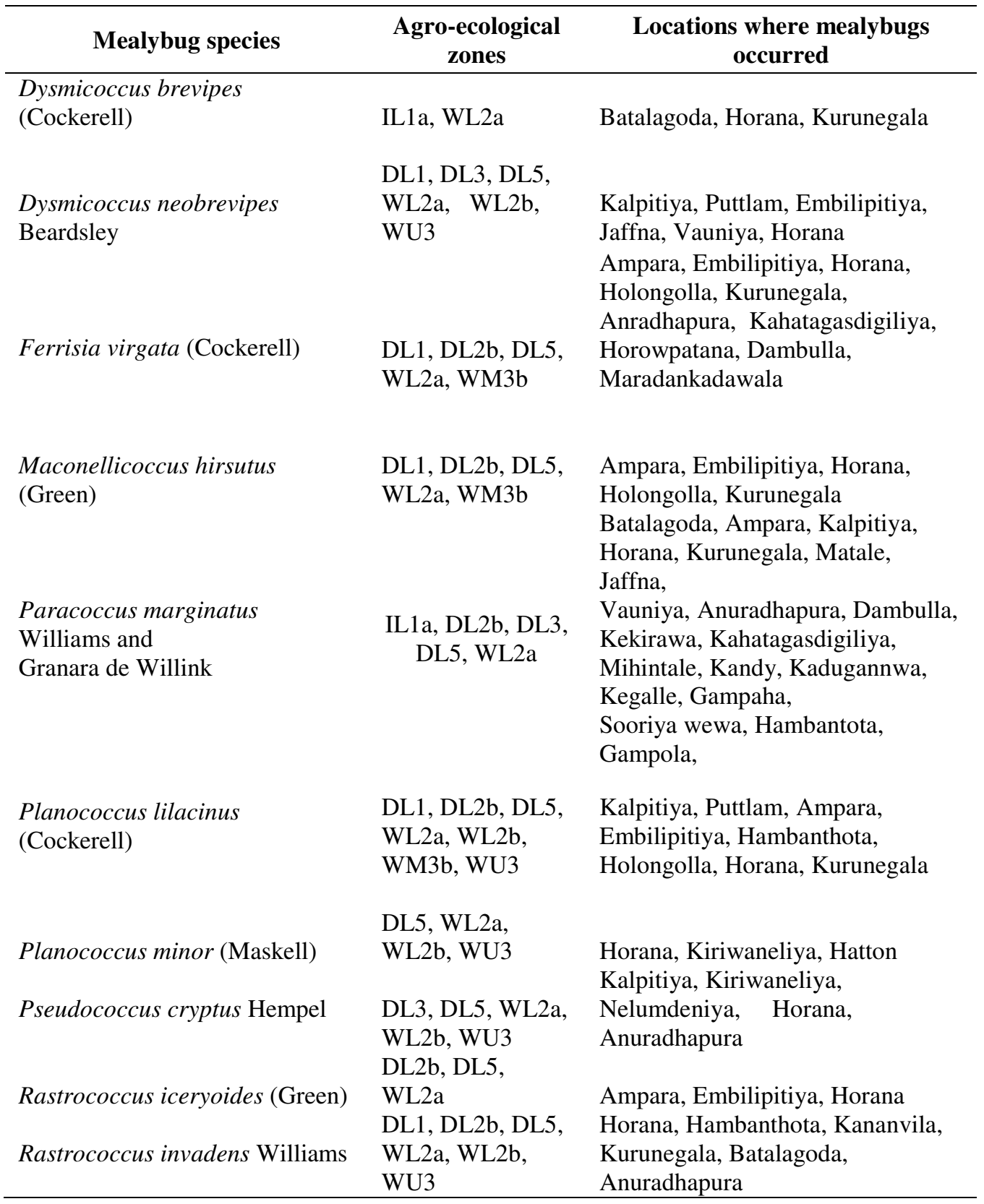

Planococcus lilacinus and $R$. invadens were the most dominant species on fruit trees, followed by $P a$. marginatus and $F$. virgata (Fig. 1). Pl. lilacinus, $R$. invadens and $F$. virgata are highly polyphagous on fruit crops. 


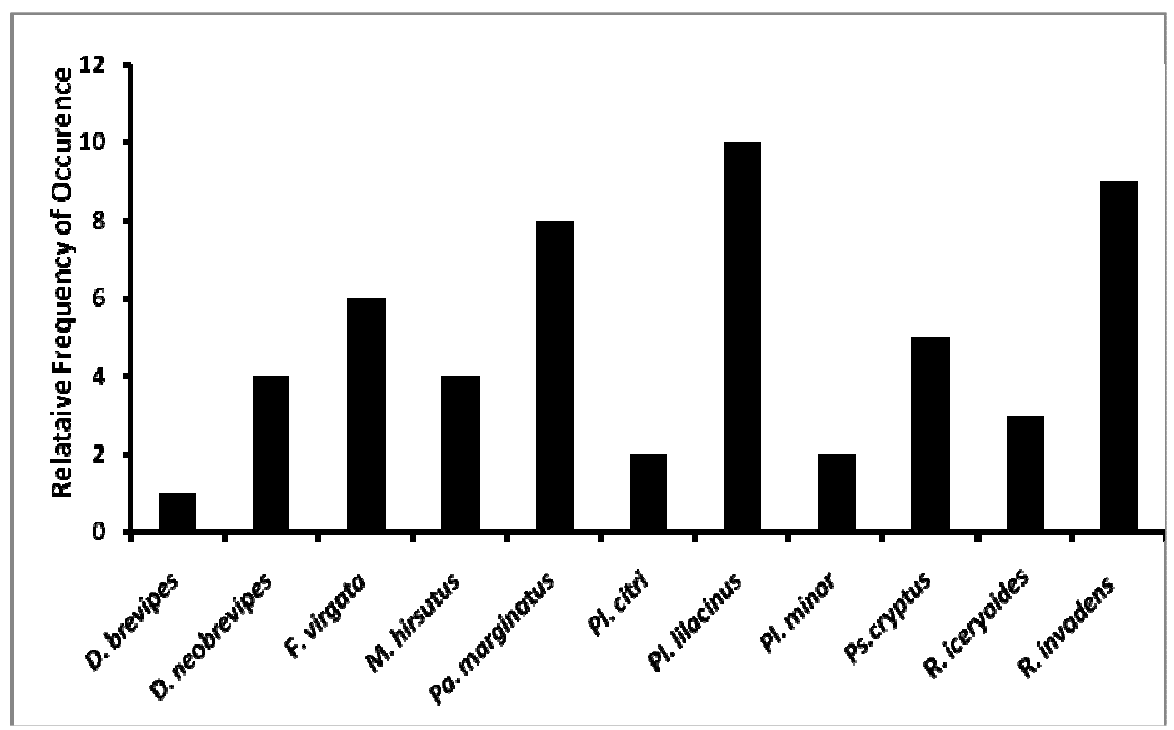

Fig. 1. Relative frequency of occurrence of each mealybug species recorded during the 2011 - 2013 fruit crop survey of Sri Lanka.

\section{Dysmicoccus brevipes (Cockerell)}

In Sri Lanka, D. brevipes (Fig. 2A) is the main insect pest in pineapple. In the survey it was found only on pineapple plants, close to the roots and in the basal parts of the leaf sheath. In other countries, $D$. brevipes is reported also on banana, mango, rambutan and guava (BenDov, 2013). Field diagnosis: live adult female oval, pink, covered by a thin layer of white mealy wax, without bare areas on dorsum; legs yellowish brown; with 17 pairs of conspicuous marginal wax filaments, the posterior pairs longest.

\section{Dysmicoccus neobrevipes Beardsley}

Dysmicoccus neobrevipes (Fig. 2B) is a recent accidental introduction to Sri Lanka, where it was first reported on banana in 2009 (Anon, 2009). In the present study, its infestation level on banana was ranked as 'high' and it was found on citrus and anona. In other countries, it has been recorded also on mango, pineapple, breadfruit, jackfruit, banana, plantain, guava, pomegranate and rambutan (Ben-Dov, 2013). Field diagnosis: body oval, gray, covered by white mealy wax, without bare areas on dorsum; legs yellowish brown; with 17 pairs of conspicuous marginal wax filaments, the posterior pairs longest, each $1 / 3$ to $1 / 2$ as long as body.

\section{Ferrisia virgata (Cockerell)}

Ferrisia virgata (Cockerell) (Fig. 2C) was the fourth most abundant mealybug species recorded in the survey (Fig. 1) and occurred mostly in the dry zone. In Sri Lanka, it was found only in low numbers on anona, guava and pomegranate, probably due to the action of natural enemies. However in other countries, it is highly polyphagous, feeding on banana, mango, citrus crops, rambutan, guava and pineapple, and is considered to be a major mealybug pest on fruit crops worldwide (Ben-Dov, 2013). Field diagnosis: body elongate 
oval and dark gray under a layer of white mealy wax, with 2 submedian longitudinal bare stripes on dorsum; with a few filamentous glassy strands of wax protruding from the body; legs brown; only 1 pair of conspicuous anal wax filaments present.

\section{Maconellicoccus hirsutus (Green)}

Maconellicoccus hirsutus (Green) (Fig. 2D), commonly known as pink hibiscus mealybug, is a highly polyphagous, invasive pest in many parts of the world. Although it was collected from guava, anona and pomegranate in the current study, it can be a serious pest on almost all the fruit crops listed in Table 1 (Ben-Dov, 2013). Infested plant parts form tightly crinkled or twisted leaves and stunted stems. Field diagnosis: body and eggs salmon pink, body covered by white mealy wax; legs yellowish brown; with only one or two pairs of very short marginal filaments at the posterior end of the body.

\section{Paracoccus marginatus Williams and Granara de Willink}

The survey revealed that $\mathrm{Pa}$. marginatus (Fig. 2I).is still spreading in Sri Lanka (Sirisena et al., 2013b) but is present at lower population levels than in previous years, probably due to the action of introduced hymenopteran parasitoids. Papaya is its primary host but mango, rambutan, anona and guava serve as secondary hosts (Galanihe et al., 2010). Field diagnosis: body elongate oval, yellow, covered in mealy wax; legs yellowish brown; with 15 to 17 pairs of short marginal wax filaments. When specimens are killed in $70 \%$ alcohol without postmortem heating, the body contents turn black in 12 - 24 hours (Muniappan et al., 2009).

\section{Planococcus citri (Risso) and Pl. minor (Maskell)}

In the survey, Planococcus citri (Risso) and Pl. minor (Maskell) (Fig. 2E, F respectively) species were found at the same level of abundance (Fig. 1) and were frequently seen on citrus. Separation of these species is impossible in life, and on slide mounts is extremely difficult; there are frequent misidentifications in reports from Southern Asia (Williams, 2004). However, Cox (1989) provided a reliable means of separation of slide-mounted specimens, based on a number of fine morphological details. The separation in the key below is fairly reliable but not as certain as that provided by Cox (1989). Field diagnosis: both species have an oval body, peach-pink, covered with a layer of mealy wax that is often thinner along a central, dorsal longitudinal stripe. Legs yellowish brown; with 18 pairs of fairly short marginal wax filaments, the anal pair slightly longer.

\section{Planococcus lilacinus (Cockerell)}

Planococcus lilacinus (Cockerell) (Fig. 2G) is the most abundant mealybug species attacking Sri Lankan fruit crops (Fig. 1). Pl. lilacinus has a very wide host range (Ben-Dov, 2013). The external wax colour and density varied significantly on different host-plants and in different environmental conditions, making field identification more difficult. Field diagnosis: body conspicuously rounded, brownish red; mealy wax covering body apart from a median dorsal bare area; wax develops into thick segmental clumps on mature females, with body color still evident at segmental lines; legs yellowish brown; 18 pairs of short marginal wax filaments present. In alcohol, preserved specimens of this species often have a lilac (mauve) colour.

In life, Planococcus lilacinus (Fig. 2G) looks very similar to Exallomochlus hispidus (Morrison) (Fig. 3A, B), a polyphagous mealybug often found on fruit trees in South-East Asia. E. mochlus could be very damaging to fruit crops if it were accidentally introduced to 
Sri Lanka, it has not been recorded from the island so far. Identification of Pl. lilacinus therefore should not be based on field appearance alone, but must be done from good quality slide mounts using the keys provided by Williams (2004), in order to ensure that the sample is not E. hispidus.

\section{Pseudococcus cryptus Hempel}

Although Pseudococcus cryptus Hempel (Fig. 2H) was recorded only from banana and citrus fruit crops in the survey, it may attack all the fruit crops listed in Table 1 except pineapple and papaya (Ben-Dov, 2013). Field diagnosis: body in life oval, slightly rounded, pale yellow and covered with mealy wax; legs yellowish brown; with 17 pairs of long, slender marginal wax filaments. Unheated specimens of Ps. cryptus in alcohol do not turn black.

\section{Rastrococcus iceryoides (Green)}

In the survey, $R$. iceryoides (Fig. 2J) was found only on mango; however, in other countries it is highly polyphagous (Ben-Dov, 2013). Field diagnosis: body conspicuously rounded, orange-red; thick mealy wax covering body, without any bare areas; legs dark brown. The marginal wax secretions do not form separate filaments but merge to form a fluted wall to the ovisac.

\section{Rastrococcus invadens Williams}

Rastrococcus invadens (Fig. $2 \mathrm{~K}$ ) is one of the dominant species on fruit crops in Sri Lanka. Although it is not new to the country (Williams, 1986), in the survey it was found as an epidemic in agro-ecological zone WL2a. A similar situation in a different area has been described by Galanihe \& Watson (2013). Field diagnosis: body in life oval, fairly flat, pale green and covered with mealy wax; legs yellowish brown; with 17 pairs of very long, slender, marginal wax filaments.

\section{Rastrococcus rubellus Williams}

$R$. rubellus was not collected in the $2011-2013$ survey. It was discovered in Sri Lanka on Plumeria sp. in 2008-9 (Galanihe \& Watson, 2013). In other parts of the world, this species has been recorded attacking mango and citrus crops (Williams, 1989, 2004). In the field, $R$. rubellus can only be distinguished from $R$. invadens by the pale pink colour of its body contents; in $R$. invadens, the body contents are pale green (Williams, 1989).

The mealybug species recorded from fruit crops in Sri Lanka can be identified using the following key. For taxonomic illustrations of slide-mounted specimens of these species, see Williams (2004). 

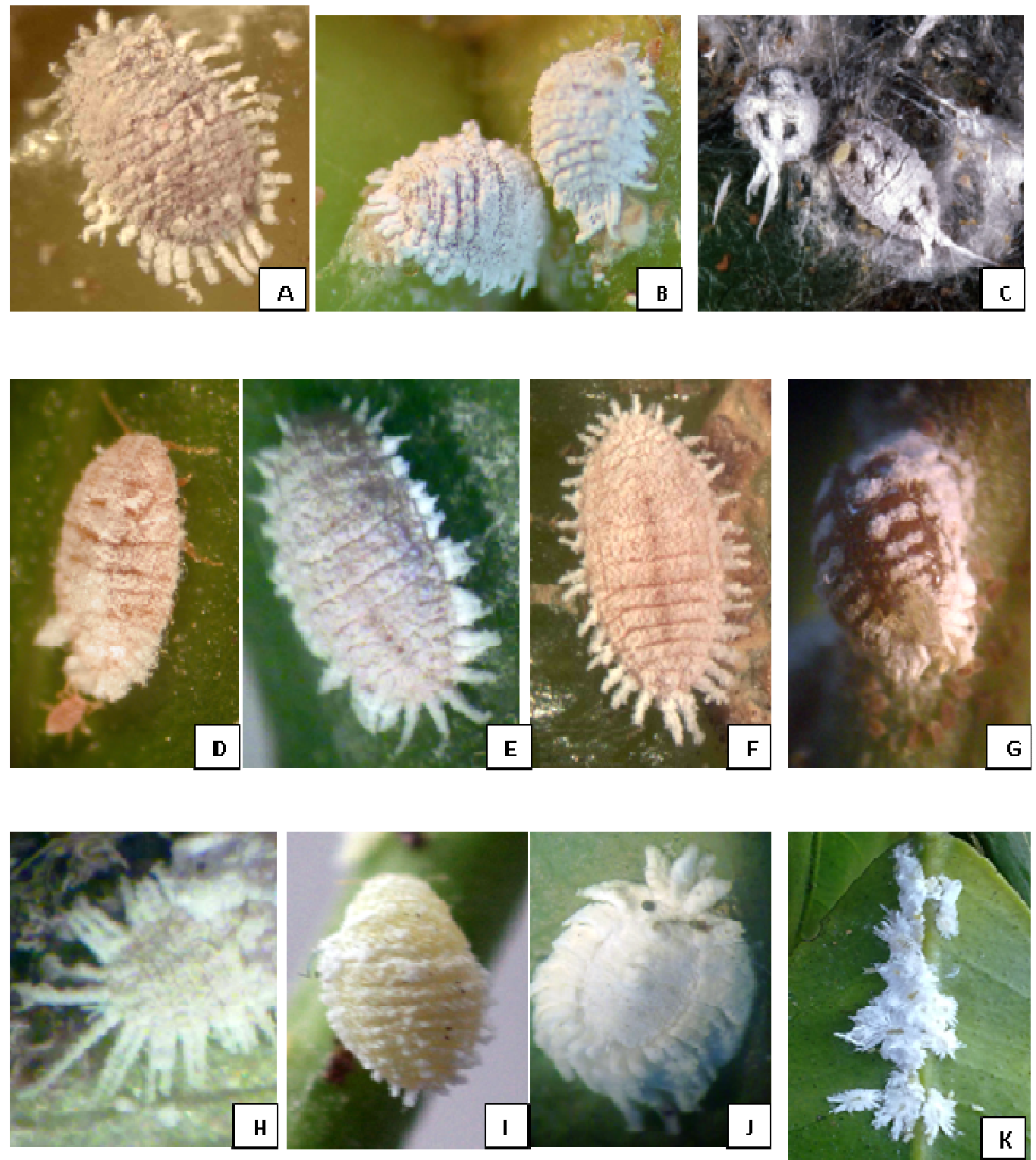

Fig. 2. Live appearance of mealybug species recorded during the fruit survey of Sri Lanka in 2011 - 2013. (A) Dysmicoccus brevipes (Cockerell), (B) D. neobrevipes Beardsley, (C) Ferrisia virgata (Cockerell), (D) Maconellicoccus hirsutus (Green), (E) Planococcus minor (Maskell), (F) Pl. citri (Risso), (G) Pl. lilacinus (Cockerell), (H) Pseudococcus cryptus Hempel, (I) Paracoccus marginatus Williams and Granara de Willink, (J) Rastrococcus iceryoides Hempel, (K) R. invadens Williams. 

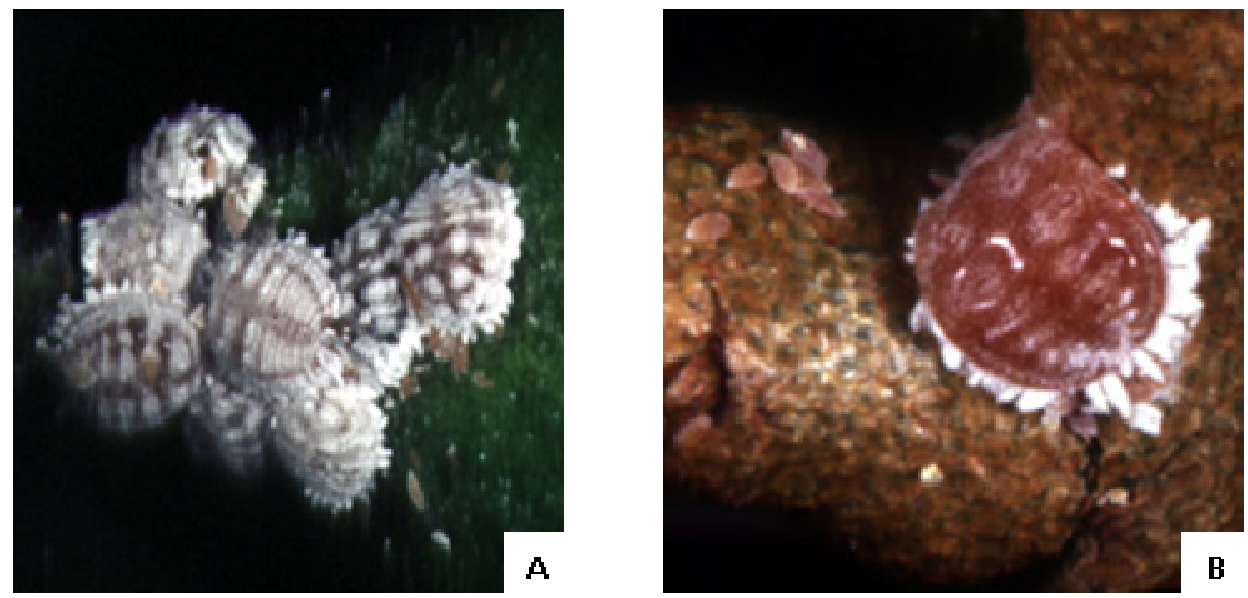

Fig. 3. Exallomochlus hispidus on fruit trees in Java, Indonesia: (A) undisturbed specimens, and (B) after heavy rain. Photographs by Dr P.A.C. Ooi.

\section{Identification Key to Adult Female Mealybugs on Fruit Crops in Sri Lanka}

1 (0) Cerarii present only on anal lobes; dorsal tubular ducts large, each with orifice surrounded by a flat sclerotized area containing 1 or more setae situated within border of the rim

Ferrisia virgata

Cerarii numbering 5 - 18 pairs; dorsal tubular ducts, if present, without setae within the border of the rim .2

2 (1) Cerarii conspicuous, each containing more than 10 enlarged setae with flattened tips; circulus $4-8$ times wider than long.................................... 3

Cerarii less conspicuous, containing enlarged setae with pointed apices. .5

3 (2) Anterior and posterior pairs of ostioles present; anal ring not flanked by long flagellate setae.

Anterior pair of ostioles absent, only posterior pair present; anal ring flanked by long flagellate setae. Rastrococcus iceryoides

4 (3) Frontal cerarii usually separated by a narrow strip of membranous cuticle Rastrococcus invadens

Frontal cerarii usually linked by a narrow strip of sclerotized cuticle

Rastrococcus rubellus 
5 (2) Oral rim tubular ducts present, each with well-developed rim. .6

Oral rim tubular ducts absent entirely 8

6 (5) Cerarii numbering 4-7 pairs, present on abdomen only; antennae 9 segmented; dorsal oral rim tubular ducts abundant Maconellicoccus hirsutus

Cerarii numbering 9-18 pairs, present on abdomen and thorax at least; antennae 8 segmented; oral rim tubular ducts relatively few 7

7 (6) Cerarii numbering 9-18 pairs, situated on membranous cuticle; auxillary setae present in anal lobe cerarii only; venter of each anal lobe with an anal lobe bar, present either forwards from apical seta or from the bar seta only

Paracoccus marginatus

Cerarii numbering 17 pairs, situated on sclerotized cuticle; auxiliary setae present in anal lobe cerarii and penultimate cerarii at least; venter of anal lobe with sclerotized area occupying much of lobe, never with a narrow anal lobe bar Pseudococcus cryptus

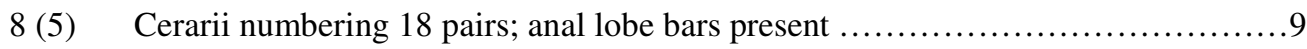

Cerarii numbering 8-17 pairs; anal lobe bars absent 11

9 (8) Dorsal setae long, sometimes longer than ventral setae; legs robust, hind tibia+tarsus usually shorter than hind trochanter+femur

Planococcus lilacinus

Dorsal setae short, much shorter than ventral setae; legs relatively slender, hind tibia+tarsus longer than hind trochanter+femur

10 (9) Ratio of lengths of hind tibia+tarsus to trochanter+femur 1.10-1.13; multilocular disc pores on posterior edge of abdominal segment VI usually forming a more-or less single row Planococcus citri

Ratio of lengths of hind tibia+tarsus to trochanter+femur 1.04-1.18; multilocular disc pores on posterior edge of abdominal segment VI usually forming a double row Planococcus minor

[Note: this is an extremely difficult separation, best done using the discriminant function provided by Cox (1989).]

11 (8) Dorsal setae on abdominal segment VIII, anterior to anal ring, much longer than other dorsal setae, almost as long as anal ring setae. Dysmicoccus brevipes 
Dorsal setae on abdominal VIII, anterior to anal ring, little if any longer than other dorsal setae

Dysmicoccus neobrevipes

\section{CONCLUSIONS}

Eleven species of mealybugs were found as a pest in fruit crops in Sri Lanka. Planococcus lilacinus, Paracoccus marginatus, Rastrococcus invadens and Ferrisia virgata were the dominant species; the first three species cause a severe damage. Planococcus lilacinus was the predominant species among all which infests a vast range of fruit crops in Sri Lanka. Mealybugs were more common in the agro-ecological zones that belong to Dry zone and very low incidences were reported from the Up country Wet zone. Monitoring of mealybug outbreaks on fruit crops is advisable, in order to detect any new introductions of invasive species as early as possible. The taxonomic key and colour plates provided in this paper are of effective tools for the identification of mealybugs in fruit crops in Sri Lanka.

\section{ACKNOWLEDGEMENT}

This project was made possible by funding from the World Bank through the Higher Education for the Twenty-first Century (HETC) project (grant no. RUSL/O-Agri/N2), Ministry of Higher Education of Sri Lanka. Authors thank California Department of Food and Agriculture Plant Pest Diagnostic Center, Sacramento, California, USA, for enabling preparation of a valuable reference collection of mealybugs for use in Sri Lanka.

\section{REFERENCES}

Anon. (2009). Banana mealybug, identification and control (in Sinhala). Leaflet. Plant Protection Service, Department of Agriculture, Peradeniya, Sri Lanka.

Ben-Dov, Y. (2013). Cyber extension: ScaleNet, Pseudococcidae catalogue. [on line]. [Accessed on 6.07.2013] Available at http://www.sel.barc.usda.gov/SCALENET/query.htm

Ceylon Chamber of Commerce (2011). Pocket Book of Agricultural Statistics, Department of Agriculture, Sri Lanka.

Cox, J.M. (1989). The mealybug genus Planococcus (Homoptera: Pseudococcidae). Bulletin British Museum (Natural History). Entomol. 58(1), 1-78.

Entwistle, P. (1972). Pests of Cocoa. Longmans, London, UK, pp. 779.

Galanihe, L.D. and Watson, G.W. (2013). Identification of Rastrococcus rubellus Williams (Hemiptera: Pseudococcidae) on mango: a new record to Sri Lanka. Trop. Agr. Res. and Extension 15(2), 7-1.

Galanihe, L.D., Jayasundera, M.U.P., Vithana, A., Asselaarachchi, N. and Watson, G.W. (2010). Occurrence, distribution and control of papaya mealybug, Paracoccus marginatus (Hemiptera: Pseudococcidae), an invasive alien pest in Sri Lanka. Trop. Agr. Res. and Extension. 13(3), 81-96. 
Green, E.E. (1922). The Coccidae of Ceylon, Part V. Dulau and Co., London, UK, pp. 345472.

Helle, W. and Sabelis, M.W. (1985). Spider mites, Their Biology, Natural Enemies and Control, Elsevier, Amsterdam, The Netherlands.

McKenzie, H.L. (1967). Mealybugs of California with taxonomy, biology, and control of North American species (Homoptera: Cooccoidea: Pseudococcidae). University of California Press, Berkeley, California, USA, pp. 526.

Miller, D.R. and Kosztarab, M. (1979). Recent advances in the study of scale insects. Annu. Rev. Entomol. 24, 1-27.

Miller, D.R., Miller, G.L. and Watson, G.W. (2002). Invasive species of mealybugs (Hemiptera: Pseudococcidae) and their threat to US agriculture. Proc. Entomol. Soc. Wash. 104(4), 825-836.

Muniappan, R., Shepard, B.M., Watson, G.W., Carner, G.R., Sartiami, D., Rauf, A. and Hammig, M.D. (2009). First report of the papaya mealybug, Paracoccus marginatus (Hemiptera: Pseudococcidae), in Indonesia and India. J. Agric. Urban Entomol. 25(1), 3740.

Parker, B.L., Skinner, M. and Lewis, T. (1995). Thrips Biology and Management. Plenum Press, New York, USA, pp. 221-224.

Punyawardena, B.V.R., Bandara, T.M.J., Munasinghe, M.A.K., Banda, N.J. and Pushpakumara S.M.V. (2003). Agro-ecological regions of Sri Lanka. Natural Resources Management Center, Department of Agriculture, Peradeniya, Sri Lanka, pp.129.

Pushpakumara, D.K.N.G., Gunasena, H.P.M. and Singh, V.P. (2011). Underutilized fruit trees in Sri Lanka. World Agroforestry Centre, South Asia Office, New Delhi, India, Volume 2.

Rosen, D. (1990). Armored Scale Insects: Their Biology, Natural Enemies and Control. Elsevier, Amsterdam, The Netherlands, Vol. 1B, pp. 688.

Sirisena, U.G.A.I., Mandanayake, M.A.R.A, Watson, G.W., Wijayagunasekara, H.N.P and Hemachandra, K.S. (2013a). Potential Pest of Rice Brevennia Rehi (Lindinger) (Hemiptera: Pseudococcidae) in Sri Lanka. pp.35-36 In: Jinadasa, D.M., Balasuriya, A., Senanayake, N., Amarasekara, M.G.T.S., Ginigaddara, G.A.S., Ranadheera, R.D.C.S., Egodawatta, W.C.P and Gunarathne, M.H.J.P. (Ed.) Proceedings of 3rd Annual Research Symposium, Rajarata University of Sri Lanka, 7th February 2013.

Sirisena, A., Jonathan, E.I. and Suresh, S. (2013b). Biocontrol of Papaya Mealybug in Sri Lanka and India. Biocontrol News and Information, CABI. 34(1), 5N-6N. [on line]. [Accessed on 6 .07.2013]. Available at www.cabi.org/BNI

Sirisena, U.G.A.I., Watson, G.W., Hemachandra, K.S. and Wijayagunasekara, H.N.P. (2012a). Mealybugs (Hemiptera: Pseudococcidae) introduced recently to Sri Lanka, with three new country records. Pan-Pac. Entomol. 88(3), 365-367. 
Sirisena, U.G.A.I., Watson, G.W., Hemachandra, K.S. and Wijayagunasekara, H.N.P. (2012b). Preparation of Hemiptera: Sternorrhyncha for identification. Trop. Agr. Res. J. 24(2), 139-149.

Verheij, E.W. and Coronel, R.E. (1992). Plant Resources of South-east Asia. Edible Fruits and Nuts. Prosea Foundation, Bogor, Indonesia.

White, F. and Elson-Harris, M. (1994). Fruit Flies of Economic Significance: Their Identification and Bionomics. CAB International, Wallingford, UK, pp. 601.

Williams, D.J. (1985). Australian mealybugs. British Museum (Natural History), London, U.K, pp. 431.

Williams, D.J. (1986). Rastrococcus invadens sp. n. (Hemiptera: Pseudococcidae) introduced from the Oriental Region to West Africa and causing damage to mango, citrus and other trees. Bull. Entomol. Res. 76, 695-699.

Williams, D.J. (1989). The mealybug genus Rastrococcus Ferris (Hemiptera: Pseudococcidae). Syst. Entomol. 14(4), 433-486.

Williams, D.J. (2004). Mealybugs of Southern Asia. The Natural History Museum. Southdene SDN. BHD., Kuala Lumpur, Malaysia, pp. 896.

Williams, D.J. and Granara de Willink, M.C. (1992). Mealybugs of Central and South America. CAB International, London, U.K, pp.644. 